\title{
Editorial
}

\section{Reengineering Education and Reimagining Rural Transformation}

With all due respect to the world's time-honored experts on education and sustainable rural development, by far the most valuable things I have learned about transforming rural people's lives have come from simply listening to their voices since it is important to bring about rural transformation from inside out. More often than not, the rural poor have been depicted as 'voiceless' 'dumb', and 'silent'. Worse to it, these silent voices are often neglected and unheard. So is the case with the rural academics. Prof. V. Chinapah adds to this list stating that the North-Anglo Saxon dominance is making marginalized academics "voiceless", "silent", "oppressed", "suppressed", "depressed" with yet another dictum "You are lazy, You're stupid, Your English is unacceptable" (personal communication, September 3, 2014). In this context, it is a timely action as I think to initiate a dialogue on reengineering our education system and reimagining the process of rural transformation.

"Re-engineering, or, to call it by its correct name, business process re-engineering, has been sweeping the business world for the last few years" (Davies, 1996, p. 11) and has not left academia either. Everyone in the current transformative landscape acknowledges the importance of reengineering education; however, most portrayals of reengineering miss the complexity of the undertaking. I believe a reengineering approach is a significant way of rethinking the nature of education to meet the challenges posed by the present day socioeconomic constraints. In this connection, Rose (2010) argued that "we need a different orientation to school reform - one that embodies a richer understanding of teaching and learning" (p. 6). It is evident that "learners and learning have changed at a much faster rate than schools have changed - or could have changed - and that a new conception of school is taking shape" (Caldwell, 2006, p. 15). Similarly, numerous education reforms and school restructuring movements have been initiated in different parts of the world, including in the developing world, over the last two decades (Fullan, 1998; Cheng, 2011). Moreover, notwithstanding the constraints, many organizations aiming at transforming society are implementing rural transformation programmes according to the local needs and situations for conferring lasting benefits on the rural population. Nevertheless, they often seem substantial in form, but in substance - not so much.

The discussion of education reengineering and rural transformation through education has often neglected a major part of the solid foundations for it - involvement of the rural 
people themselves. There is nothing wrong with theory in sustainable rural transformation. Long-standing concepts hold up well. However, a pragmatic approach to addressing the rural transformation endeavors is to involve the rural people themselves since "turning the rural sector into an engine of growth is now more important than ever" (Gurría, 2009, para. 3). But how far have we gone to that direction? I believe, as Margolis (2014) believes, "educators need to change how they reach struggling learners" (para. 5). In this context, it is worth reiterating what Severn Suzuki (with her friends Vanessa Suttie, Morgan Geisler, and Michelle Quigg) as a kid had said to us the grown-ups long back in 1992 - "You must change your ways" (We Canada, 2012). Have we been able to change our ways since then? And if we cannot change ourselves, it may merely be a fantasy to think about changing rural lives. I am fascinated by Severn's wishful thinking "If all the money spent on war was spent on ending poverty and finding environmental answers, what a wonderful place this earth would be!" That is as true today as it was in 1992. Can we now accept her challenge - "Make your actions reflect your words"? Maybe a part of taking up her challenge can be making a meaningful participation of the concerned local stakeholders in our forthcoming mega events - listening to their voices and seeking solutions from themselves.

To speak a(n) (un)truth, I have hardly seen a rural farmer participating in a world conference on rural development, nor have I talked to a student who has failed in a grade level in any discussion of grade retention issue. Following this line of thinking, I need to make the point clear that present education system has a pronounced level of what social scientists call "Educational Darwinism" (Spencer, 1857, as cited in Halsall, 1997; Chartier, 2008). Should this policy be adopted, only a few children will be allowed to continue their education and thus will be capable of success; the rest remain failures. Too often, the challenges of rural education are derelict since "non-attendance, early dropout, adult illiteracy and gender inequality are disproportionately high in rural areas - paralleling concentration of poverty in villages. Urban-rural disparity in educational investments and in the quality of teaching and learning is widespread and persistent" (UNESCO INRULED, 2001, p. 1). On the other hand, this backdrop also calls for inspirational vision that improving the exam result is not tantamount to improving the quality of schooling (West, Ainscow, \& Stanford, 2006, p. 49). Therefore, I strongly feel the need to take a transformative turn in how we think and act.

Much ink has been spilled trying to show the diverse needs of rural communities and some pathways, especially education, to address them. It is increasingly realized that rural transformation can be accelerated by effective educational programmes and that education gains a lot from the experiences of rural development (Pareek, 2005, p. i). Therefore, we recognize that "any attempt to readdress our world's increasing inequity, poverty and widening human development disparities is possible through access to relevant, equitable and effective education of our rural people" (Chinapah, 2011, p. xi). However, such "educational programs have to become a vital part of this transformation through 
committed partnership of the government, communities, business, and civil society as a whole" (UNESCO INRULED, 2001, p. ix). UNESCO INRULED (2001) further demands adjusting and re-directing national educational priorities, strategies and resources to the specific conditions of diverse and changing rural communities. However, the hope of education working for radical change of the society from within the conventional cycle is only wishful thinking (Pareek, 2005, p. 3). Therefore, it's high time we recognized multiple forms of knowledge (see Parajuli's article) and integrated non-formal and informal education into the mainstream formal education for capital formation and self sufficiency of the rural communities (see Sharma's article).

As educational leaders, environmentalist, sustainable development workers and experts on our own areas, we are tackling complex challenges and making audacious choices to better educate our children, and transform our rural societies. I believe the articles in this issue contribute towards such a discourse. Most importantly, the articles in this issue focus on the vital areas of rural transformation such as policies and programmes in developing countries, recognize rural and indigenous knowledges, and highlight issues on reinventing rural education. Therefore, the aim of the papers presented in this issue is to initiate a dialogue and help develop a framework for policy and action to make education the vehicle for rural transformation.

As part of this very discourse, Rabinowicz and Chinapah, in the first article, argue that the developing world is in crisis especially in responding to the world's instability in the economy and environment. Revealing the fact that rural people are among the most vulnerable groups who make up the majority of the poor, the authors suggest making sustainability a part of the process of transformation making education a catalyst for it. They further elaborate on the concept of sustainable rural transformation and place emphasis on why education and good practices are important to endorsing an equitable sustainable rural transformation. In response to the challenges of globalization and local development, educational reengineering at its best and reform at the least is inevitably becoming one of the major trends even in the developing world (Yin, 2005, p. 174). Therefore, as we reimagine rural transformation, the contribution of education needs to be maximized and thereof underscored.

Similarly, the second article in this issue critically discusses how inclusion and exclusion manifest for rural people. In doing so, Agbenyega applies Bourdieu's sociocritical theoretical framework that provides a three pronged approach (Habitus, Capital and Field) which he has utilized to theorize education for rural transformation. Agbenyega further argues that education for rural transformation requires a critical appraisal of policies and programs leading to the creation of sustainable employment opportunities for rural people to ensure social justice. At this point, it is important to note that "social justice lessons rarely come ready-made. The issues are often wrapped in controversy and debate, 
and the active learning that results can lead in unexpected directions" (Scherer, 2009, para. 1). Therefore, in Agbenyega's words, a thoughtful examination of 'doxa' is called for here.

Writing about a teacher's belief and perspective, Appavoo explains the low primary school performance in the rural district of Black River, Mauritius. Appavoo brings forth the issue of pass rates being very low over many years and goes on to explore the situation from a teacher's perspective. Unveiling the causes which persistently hamper student progress, Appavoo in the third article in this issue reveals that although children in Black River are on a par with their counterparts in other rural and urban areas in respect to access to school facilities, their motivation of learning at home is not up to the mark. The author comes to the conclusion that without sustained parental support, learning performance of students in the Black River region is unlikely to improve. Therefore, he suggests implementing community-based strategies to encourage parents to support the education of children. This article reminds us of the need to reimagine schooling when it does not matter at home. Schooling is not only attending a school, but it is more of following up and even participating in children's learning at home and everywhere. Can we reimangine schooling and education in this respect? Can we make students feel like they matter - not because to increase the number of students to receive the government fund (PCF) but because we really care children's education? Isn't it time to challenge our own thinking?

H. S. Bhola's article "Education for Rural Transformation in Thailand" takes us back to understanding the concepts of rural condition and education. The author points to the need for "education" itself to undergo transformation to serve as the lever of rural and urban transformation. He also suggests a model for planned action. He believes that new technologies of communication can expand, enrich and enhance the role of literacy, but will never supplant it. According to the author, adult literacy helps connect with the important educational theme of our times, i.e., lifelong education.

The fifth article in this issue projects the challenges Education for Rural Transformation (ERT) professionals face in the post 2015 era. More particularly, Ahmed, the author, provides a background to the on-going discourse on post-2015 global development agenda mentioning some key points from the UN Secretary General's report on MDG progress. He further examines the recommendations of the High Level Panel on post-2015 agenda through an ERT perspective and indicates that the premise and rationale of ERT has received scant attention in the future development agenda discourse.

Sharma has assessed the role of Community Learning Centers (CLCs) in Nepal and has documented the potential contributions of the CLCs in the process of rural transformation. Referring to a case study, Sharma claims that CLCs can be instrumental in rural transformation by offering diverse programs in education and community services such as: early childhood care and development, good quality primary education for all children, second chance basic education for youth, literacy and post literacy programs, women education program, vocational skill development, income generating programs 
and community development services for improving the quality of life of rural people. He further suggests that CLC has potential to offer assistance to the students of local schools in improving their academic achievement and to serve as a local institutional base offering technology-based open and distance learning opportunities and engage rural people in lifelong learning.

The final article in this issue is about acknowledging multiple forms of knowledge. Parajuli, the author, claims that Nepali policy documents have not given any direct consideration to education as a means for social transformation. Though there have been some attempts towards seeing education as a means for rural transformation, Parajuli argues on the need for identifying local practices of knowledge gaining and sharing as accepted modes of knowing and educating. He calls for recognizing multiple forms of knowledge and also valuing indigenous practices of knowing and educating. More importantly, Parajuli strongly suggests that we see the knowing beyond the formal and non-formal schooling process and thus end the binary and derogatory practice of labeling people as illiterate.

All articles in this issue are the contribution towards a discourse on ERT. I believe such discourse needs to be continued, extended and strengthened with more wider participation of actors at all levels. Maybe we can listen to the voices of school age children and reach out to rural people and communities. A careful reading of all seven articles in this issue also reinforced my own belief that we can put in our time and whatever energy we have to push the boundaries of how we view education.

\section{References}

Caldwell, B. J. (2006). Re-imagining educational leadership. Thousand Oaks, CA: Sage. Chartier, T. (2008, September 4). Educational Darwinism is here. Retrieved from http://atlanticfreepress.com/news/1/4909-educational-darwinism-is-here-.html

Cheng, Y. C. (2011). Towards the 3rd wave school leadership. Revista de Investigación Educativa, 29(2), 253-275.

Chinapah, V. (2011). Introduction and summary. In V. Chinapah (Ed.), Education for rural transformation (ERT): National, international and comparative perspectives (pp. xixvi). Stockholm, Sweden: Institute of International Education, Stockholm University.

Davies, B. (1996). Reengineering school leadership. International Journal of Educational Management, 10(2), 11-16. doi: 10.1108/09513549610105696

Fullan, M. (1998). The meaning of educational change: A quarter of a century of learning. In Hargreaves, A., Lierberman, A., Fullan, M., \& Hopkins, D. (Eds.), International handbook of educational change (pp. 214-228). Dordrecht, The Netherlands: Kluwer Academic Publishers.

Gurría, A. (2009, February 16). Spain's rural policy. Presented at the Ministry of the Environment and Rural and Marine Affairs, Madrid, Spain. Retrieved from http://www. oecd.org/fr/presse/presentationofthestudyonspainsruralpolicy.htm 
Halsall, P. (1997). Herbert Spencer: Social Darwinism, 1857. In P. Halsall (Ed.), Internet modern history sourcebook. New York, NY: Fordhan University. Retrieved from http://www.fordham.edu/halsall/mod/spencer-darwin.asp

Margolis, H. (2014, September). Giving students a reason to try. Educational Leadership, 72(1). Retrieved from http://www.ascd.org/publications/educational-leadership/sept14/ vol72/num01/Giving-Students-a-Reason-to-Try.aspx

Pareek, U. (2005). Education and rural development (2nd ed.). Hyderabad, India: ICFAI University Press.

Rose, M. (2010, April). Reform: To what end? Educational Leadership, 67(7), 6-11.

Scherer, M. (2009, July). Introduction: A responsible investment. Educational Leadership, 66(8). Retrieved from http://www.ascd.org/publications/educational-leadership/ summer09/vol66/num10/A-Responsible-Investment.aspx

UNESCO International Research and Training Center for Rural Education. (2001). Education for rural transformation: Towards a policy framework. Baoding, China: Author.

We Canada. (2012, August 16). Severn Cullis-Suzuki at Rio Summit 1992 [Video file]. Retrieved from http://www.youtube.com/watch?v=oJJGuIZVfLM\&hd=1

West, M., Ainscow, M., \& Stanford, J. (2006). Achieving sustainable improvements in urban schools. In M. Ainscow \& M. West (Eds.), Improving urban schools: Leadership and collaboration (pp. 46-57). Berkshire, England: McGraw-Hill.

Yin, C. C. (2005). New paradigm for re-engineering education: Globalization, localization and individualization. Education in the Asia-Pacific region: Issues, concerns and prospects (Vol. 6). Dordrecht, The Netherlands: Springer.

Rebat Kumar Dhakal

School of Education, Kathmandu University Email: rebat@kusoed.edu.np 